\title{
Factors Affecting Success of Micro and Small Business Enterprises: In Case of Some Selected Woredas of Hadiya Zone, Snnpr, Ethiopia
}

\author{
Lemabo Jaboro Satore \\ Lecturer and Quality assurance officer at Rift Valley University
}

\begin{abstract}
Micro and Small Enterprises play an important economic role in many countries and recognized as an important vehicles of economic diversification, employment creation, income generation and poverty alleviation .However performance of micro and small enterprises (MSEs) remains to be a major problem delaying MSEs from playing their productive role in the economy.Therefore, the motive of this study is intended to fill this gap byanalyzing success factors on performance of MSEs in Hadiya zone. This research was carried out through descriptive and explanatory research design.Furthermore the approach that was followed in this particular study was quantitative and qualitative.Purposive sampling technique was used to select sub sectors of MSEs (food and beverage, wood and metal, merchandise and retail shop, and textile and garment). Sample size of 161 from target population of 269 was determined by using stratified proportional random sampling method and simple random sampling technique was used to select respondents from each stratum. The descriptive (mean, percentage and standard deviation) and inferential (Pearson correlation coefficient and multiple linear regression) statistical tools were used to analyse collected data. The results of the regression analysis showed that management, marketing, technological, political-legal, planning and financial factors were statistically significant at 5\% significance level and had positive relationship with the performance of MSEs.Based on the research results, it is recommended for MSEs have responsibility to adopt better technology that will enable them increase efficiency, improve quality and diversity of products. The government has also encourage and support MSEs on how to identify and adopt appropriate technology based on the need of specific types of products, service or consumer needs.
\end{abstract}

Keywords: MSEs, performance, success factors, political-legal

DOI: $10.7176 /$ RJFA/11-23-01

Publication date: December $31^{\text {st }} 2020$

\section{Background of the Study}

Micro and Small Enterprises (MSEs) can define as one, which are independently owned and operated, and not dominate in its field of operation. It also defined in terms of sales volume and by the number of employees in the firm. MSEs may define as business with a small number of employees. The legal definition of MSEs often varies from country to country and from industry to industry, in the United States generally under 100 employees while under 50 employees in European Union (Endalkachew,2008).

In Ethiopia, according to Ministry of Trade and Industry MoTI(1997), the definition of MSEs as follows:

- Micro Enterprises are business enterprises found in all sectors of the Ethiopian economy with a paid-up capital (fixed assets) of not more than Birr 20,000, but excluding high-tech consultancy firms and other high-tech establishments.

- Small Enterprises are business enterprises with a paid-up capital of more than Birr 20,000 (\$2,500) and less than Birr 500,000 (\$62,500) and excluding high-tech consultancy firms and other high-tech establishments.

Nowadays employment is very serious issue and offering jobs to all citizens of a country also challenging task to every government. As a result, different governments are framing different strategies and policies to create job opportunities. One strategy as to create jobs and accommodate maximum number of citizens has been emerged, i.e., the establishment of MSEs. This form of sector comes in to existence with the aim to accommodate as much as possible numbers of member owned enterprises with affordable working capital and management (Ermias, 2011).

In Ethiopia, MSEs are the second largest employment-generating sector next to agriculture. A national survey conducted by Central Statistics Agency CSA (2003) indicates that more than 1.3 million people in the country are engaged in informal sector and small manufacturing businesses.

The MSEs are also as an important force to generate employment and more equitable income distribution, to activate competition, exploit niche markets, enhance productivity and technical change, and through all of these stimulate economic development. Therefore, the Government of the Federal Democratic Republic of Ethiopia has recognized and paid due attention to the promotion and development of MSEs for they are important vehicles to address the challenges of unemployment, economic growth and equity in the country. To this effect, the government has formulated a National Micro and Small Enterprise Development and Promotion Strategy, which 
enlightens a systematic approach to alleviate the problems and promote the performance of MSEs (MoTI, 1997).

MSEs caught the attention of development practitioners and policy makers recently not only because of their importance in terms of generating employment also because of various other attributes. Some of these are:

- MSEs are breeding ground for entrepreneurs.

- The sector has high employment generating capacity, and is less capital intensive.

- It is highly competitive, flexible, and innovative.

Having recognized the importance of the MSEs sector to the economy, the Federal Government of Ethiopia has issued an MSEs Development Strategy in 1997 followed by the proclamation for the establishment of the Federal Agency for MSEs Development in 1998 (MoTI, 1997).

It is obvious that agriculture is still the backbone of Ethiopian economy and medium and large companies are contributing for economic growth and development of the country. Even though no complain is required regarding their contributions, MSEs were not considered in the past decades as they have invaluable contributions in the economic development of countries like other sectors. Currently, Ethiopian government has given priority and planned to work aggressively on MSEs to complement with the objective of the 5 years of Growth and Transformation Plan (GTP) that is focuses on industrial development in the country. The sector is expects to plays a significant role as an instrumental in curbing the challenges of unemployment, poverty and to accelerate economic growth.

\section{Statement of the Problem}

Micro and Small Enterprises play an important economic role in many countries and recognized as an important vehicles of economic diversification, employment creation, income generation and poverty alleviation. Ethiopia is one of the developing countries which have taken measures to enhance the operation of MSEs by considering their contribution. The Government of the Federal Democratic Republic of Ethiopia has recognized and paid due attention to the promotion and development of MSEs for they are important vehicles to address the challenges of unemployment, economic growth and equity in the country (MoTI, 1997:5). Thus it evinced that the government exert much in ensuring the continuity of the MSEs for the growth and expansion of the enterprise in the sector. However performance of MSEs remains to be a major problem hindering MSEs from playing their productive role in the economy

Mulu, (2009) made study on the growth of micro enterprises in Ethiopia by randomly selected 975 MSEs from six major town of Ethiopia. The study reveals that those MSEs owner with some business experience, high school completed and MSEs headed by male are grow faster. Moreover, MSEs engaged in manufacturing and service sector, MSEs located at traditional market and MSEs with business license have significant effect on the growth of MSEs. Owners' age have no significant effect on the growth of MSE.

According to Paul \& Rahel Wasihun (2010), the study further indicated that participation in social capital and networking schemes such as Iqub was critically helpful for long-term survival of the enterprises. Businesses that did not participate in Iqub schemes regularly were found to be 3.25 times more likely to fail in comparison with businesses that did, according to the study. In their study, based on the survey covering 123 business units in four Kebeles of Nifas Silk- Lafto and Kirkos sub-cities of Addis Ababa, and aimed to investigate the constraints and key determinants of growth, particularly in employment expansion, they found out that the studied enterprises registered $25 \%$ increment in the number of total employment they created since their establishment with an average annual employment rate of $11.72 \%$. With regard to the sources of initial capital of the studied enterprises, the study indicated that, the main ones were loan from MFI (66.7\%), personal savings/Iqub (17.5\%),and loan from family/friends(17.1\%). Moreover, the concrete problems that the targeted MSEs faced at their startup were lack of capital (52.8\%), skills problem (17.9\%) and lack of working space (17.1\%).Moreover, Daniel (2007), identified that lack of raw material, stiff competition and shortage of working capital.

According to Eshetu and Zeleke (2010) conducted longitudinal study to assess the impact of influential factors that affect the long-term survival and viability of small enterprises by using a random sample of 500 MSEs from 5 major cities in Ethiopia. According to this research, that lasted from 1996-2001, the factors that affect the long term survival of MSEs in Ethiopia are found to be adequacy of finance, level of education level, poor managerial skills, level of technical skills, and ability to convert part of their profit to investment. This is so because the findings of the study revealed that businesses that failed, during the study period were characterized by inadequate finance (61\%), low-level of education (55\%), poor managerial skills $(54 \%)$, shortage of technical skills $(49 \%)$, and inability to convert part of their profit to investment (46\%).

According to Mulugeta (2011), has also identified and categorized the critical problems of MSEs into market related problems, which are caused by poor market linkage and poor promotional efforts institution-related problems including bureaucratic bottlenecks, weak institutional capacity, lack of awareness, failure to abide policies, regulations, rules, directives, absence of training to executives, and poor monitoring and follow-up; operator-related short coming slick developing dependency tradition, extravagant and wasting behavior, and lack of vision and commitment from the side of the operators; MSE-related challenges including lack of selling place, 
weak accounting and record keeping, lack of experience sharing, and lack of cooperation within and among the MSEs and finally, society-related problems such as its distorted attitude about the operators themselves and their products.

According to Teklemariam \& Gemechu (2016), were conducted with the intention of assessing the factors affecting performance of the MSE particular to manufacturing, trade and service sectors. In their study, based on the survey covering 278 business units in case of Bench Maji, sheka, and Kefa .The study indicated that land availability (59.1\%), technological (56.4\%), management (21.4\%), infrastructural $(34.9 \%)$, political $(40.5 \%)$ and financial factor $(35.5 \%$.

Moreover, Teklemariam and Gemechu (2016) carried out the study on assessing the factors affecting performance of the MSE. The study recommended that a study must be carried out factor in other elements of affecting factors and assess their impact on performance of MSEs. Habtamu (2012) in his areas of further study suggested a study on analyzing other elements of factors and assess their impact on performance of MSEs. This study seeks to fill gap as identified above. Therefore, the study tries to investigate factors for the performance of MSEs in Hadiya zone by taking success factors (management, planning, marketing, technology, financial and political-legal) in to account.

\section{III.Hypothesis}

After reviewing theoretical and empirical works determine independent variables and the dependent variable of the study, based on this following hypotheses were developed and tested using beta coefficient.

- H1: There is relationship between management factor and performance of micro and small enterprises

in Hadiya zone.

- H2: There is relationship between planning factor and performance of micro and small enterprises in Hadiya zone.

- H3: There is relationship between financial factor and performance of micro and small enterprises in Hadiya zone

- H4: There is relationship between technological and performance of micro and small enterprises in Hadiya zone.

- H5: There is relationship between marketing factor and performance of micro and small enterprises in Hadiya zone.

- H6: There is relationship between politico-legal factor and performance of micro and small enterprises in Hadiya zone.

\section{IV.LITERATURE REVIEW}

According to Workneh (2007) research undertaken in KolfeKeraneo sub-city of Addis Ababa indicated that lack of capital, lack of market, unfavorable policy, and inadequate infrastructure, absence of adequate and relevant training, bureaucratic structure and procedures are among constraints faced by MSEs. Similarly, Adil's (2007) research carried out in Addis Ababa shows that inappropriate government intervention, shortage of capital, location disadvantage, and lack of market and lack of display room are the major challenges that obstruct MSEs.

According to Eshetu and Zeleke (2010) conducted longitudinal study to assess the impact of influential factors that affect the long-term survival and viability of small enterprises by using a random sample of 500 MSEs from 5 major cities in Ethiopia. According to this research, that lasted from 1996-2001, the factors that affect the long term survival of MSEs in Ethiopia are found to be adequacy of finance, level of education level, poor managerial skills, level of technical skills, and ability to convert part of their profit to investment. This is so because the findings of the study revealed that businesses that failed, during the study period were characterized by inadequate finance (61\%), low-level of education (55\%), poor managerial skills (54\%), shortage of technical skills $(49 \%)$, and inability to convert part of their profit to investment $(46 \%)$.

According to Assegedech (2010), Shortage of funds discourages the smooth operation and development of MSEs. Even if there are credit facilities, some of the MSEs do not use the money for the intended purpose. They rather divert it for other unintended and on productive expenditures. Consequently, the enterprises fail to return the money back to the lender on time. This can result in a loss of credibility to get repeated loans when needed." In addition competition is also another problem that hinders the performance of MSE. She explained it as: "As is mostly the case and common recognition, "Competition is Cruel", which implies that some larger companies in relation to MSEs have advantages due to: selling at reduced price without reducing product quality using economies of scale, customer targeting capacity, proper and intensified product/service advertising capacity, good personal contacts and networks, sound industry reputation and sufficient information regarding existing market and capacity to exploit more market opportunities."

According to Tegegne \& Meheret (2010) was conducted with the intention of assessing the contribution of the MSE strategy to poverty reduction, job creation and business development. The raised causes for this gloomy 
prospect of business were not growing (33\%), lack of finance (13\%), lack of market (11\%), and lack of working space $(4 \%)$. The major constraints identified by various studies on MSEs in Ethiopia are associated with market and finance problems. The causes of market-related problems of MSEs engaged in metal and wood work are shortage or absence of marketing skills, poor quality of products, absence of marketing research, shortage of market information, shortage of selling places, and absence of sub-contracting (FeMSEDA 2007). The product line of MSEs activities in Ethiopia was relatively similar(Assegedech, 2010). Accordingly she states that: “...Lack of product diversity, however, is prevalent and as a result similar products are overcrowding the market. Some micro enterprises shift from one product to another, and in doing so, capture better market opportunities. Nevertheless, as soon as the market has established itself, a multitude of further microenterprises start of find the same business and this causes the selling price to fall immediately.

According to Paul \& Rahel Wasihun(2010), the study further indicated that participation in social capital and networking schemes such as Iqub was critically helpful for long-term survival of the enterprises. Businesses that did not participate in Iqub schemes regularly were found to be 3.25times more likely to fail in comparison with businesses that did, according to the study. In their study, based on the survey covering 123 business units in four Kebeles of Nifas Silk- Lafto and Kirkos sub-cities of Addis Ababa, and aimed to investigate the constraints and key determinants of growth, particularly in employment expansion, they found out that the studied enterprises registered $25 \%$ increment in the number of total employment they created since their establishment with an average annual employment rate of $11.72 \%$. With regard to the sources of initial capital of the studied enterprises, the study indicated that, the main ones were loan from MFI (66.7\%), personal savings/Iqub (17.5\%), and loan from family/friends(17.1\%). Moreover, the concrete problems that the targeted MSEs faced at their startup were lack of capital (52.8\%), skills problem (17.9\%) and lack of working space (17.1\%).Moreover, Daniel (2007), identified that lack of raw material, stiff competition and shortage of working capital.

According to Mulugeta (2011), has also identified and categorized the critical problems of MSEs into market related problems, which are caused by poor market linkage and poor promotional efforts institution-related problems including bureaucratic bottlenecks, weak institutional capacity, lack of awareness, failure to abide policies, regulations, rules, directives, absence of training to executives, and poor monitoring and follow-up; operator-related short coming slick developing dependency tradition, extravagant and wasting behavior, and lack of vision and commitment from the side of the operators; MSE-related challenges including lack of selling place, weak accounting and record keeping, lack of experience sharing, and lack of cooperation within and among the MSEs and finally, society-related problems such as its distorted attitude about the operators themselves and their products.

According to Teklemariam \& Gemechu (2016), were conducted with the intention of assessing the factors affecting performance ofthe MSE particular to manufacturing, trade and service sectors. In their study, based on the survey covering 278 business units in case of Bench Maji, sheka, and Kefa .The study indicated that land availability (59.1\%), technological (56.4\%), management $(21.4 \%)$, infrastructural $(34.9 \%)$, political $(40.5 \%)$ and financial factor (35.5\%). The major constraints identified by various studies on performance of MSEs in Ethiopia are associated with land availability and technological problems.

\section{Conceptual Framework}

The researcher was chosen six success factors to investigate. These were: planning factor, financial factor, managerial factor, technological factor, political-legal factor, and marketing factor. Some of the literature sources written by different authors in the field that help to insight the small business success factors adopted their related studies like (Lussier., 1995; Praag.,2003; Shonesy.et al., 2004; Walker \& Brown., 2004; Lussier \& Halabi., 2010).

- Politico-legal Related Factors: Admasu (2012), has identified eight challenges that cause failure of small business enterprise, out of those politico-legal problems are the major ones including bureaucratic systems, frequent mention of political uncertainty, unfavorable laws, in addition to high taxes indicate that government and its regulation are major obstacles to MSE operations.

- Financial factors: presence of adequate capital, sufficient loan, and efficient financial market in terms of facilitating financial resources to entrepreneurs are the major success in doing business.

- Management Experience: Businesses managed by people with prior management experience have a greater chance of success than firms that are managed by people without prior management experience.

- Planning: Businesses that develop specific business plans have a greater chance of success than firms that do not.

- Technology: A choice of technology and innovative capacity is another important factor determining growth of MSEs. Businesses that develop best technology and innovative capacity have a greater chance of success than firms that do not.

- Marketing: Business owners without marketing skills have a greater chance of failure than owners with marketing skills. The relationship of independent and dependent variables can be expressed and shown in the figure below. 


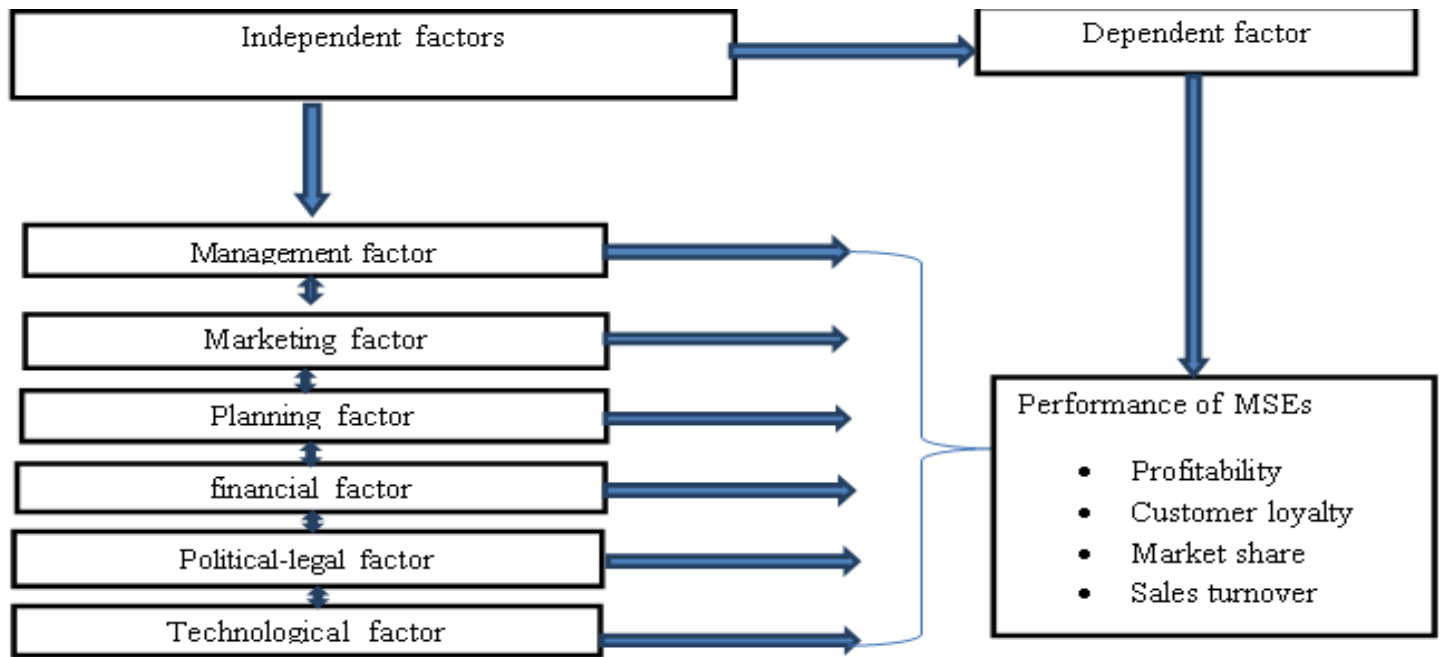

Figure1: Conceptual frame work

Source: Adopted with modification from Gemechu \&Teklemariam(2016)

\section{VI.METHODOLOGY OF THE STUDY}

\section{Research design}

The research was employed descriptive and explanatory research design. The research describes and critically analyzes the success factors on the performance of MSEs in Hadiya zone. Second, the study was employed explanatory research design to determine the casual relationships between independent and dependent variables. In addition to this research was utilized cross-sectional approach to collected relevant data at a single point in time. The reason for preferring a cross-sectional study was due to the vast nature of the study and limitation of time and obtaining information from population at a single time was reasonable strategy for pursuing many descriptive researches (Janet, 2006). Also the study mixing qualitative and quantitative approaches give to cover the method weakness (Mark, 2011; Creswell, 2009).

Sampling strategy and procedures

Soro Woreda, Shone town, Shashogo woreda, Misha woreda and Hosanna city administration was purposely chosen among 13 woreda and four city administration in Hadiya zone based on their establishment. Also, purposive sampling technique was used to select the strata (food and beverage, wood and metal, merchandise and retail shop, and textile and garment) firms based on their high concentration, better record keeping and registration.

Sampling technique

Sample size of 161 from target population of 269 was determined (Yamane, 1967).And stratified to each stratum proportionally and randomly selects respondents from each MSEs.

$n=\frac{N}{1+N\left(e^{2}\right)}$, Where $\mathrm{n}=$ sample size, $\mathrm{N}=$ population size, $\mathrm{E}=$ error limit (basis with $95 \%$ Confidence level.) $269=$ population size Error limit $=0.05$ basis of $95 \%$ confidence level, $n=269 \div(1+269 \times .0025)=160.837=161$ Proportional sample size allocation to each sector of MSES was determined by the following formula: $N_{i}=(n *$ $\left.N_{j}\right) / N$ Where, $\mathrm{n}$ is sample size of MSE sector, n is sample size of the study $N_{i}$ is total population size $N_{j}$ is population size of $\mathrm{j}$ MSE sector

Table 1: Number of MSEs in some selected woredas

\begin{tabular}{|c|c|c|c|c|c|c|c|}
\hline \multirow[t]{2}{*}{ Sector } & \multicolumn{5}{|c|}{ woreda (town) } & \multirow{2}{*}{$\begin{array}{l}\text { Target } \\
\text { population }\end{array}$} & \multirow[t]{2}{*}{ Sample size } \\
\hline & Soro & Shashogo & misha & Shone & Hosanna & & \\
\hline food and beverage & 26 & 8 & 8 & 11 & 68 & 121 & $121 / 269 * 161=72$ \\
\hline $\begin{array}{l}\text { Wood and meta } \\
\text { work }\end{array}$ & 12 & 8 & 9 & 7 & 42 & 78 & $78 / 269 * 161=47$ \\
\hline $\begin{array}{l}\text { merchandise } \\
\text { retail shop }\end{array}$ & 12 & 8 & 5 & 8 & 10 & 43 & $43 / 269 * 161=26$ \\
\hline Textile and Garment & 4 & 5 & 4 & 6 & 8 & 27 & $27 / 269 * 161=16$ \\
\hline Total & 54 & 29 & 26 & 32 & 128 & 269 & 161 \\
\hline
\end{tabular}

Source: Hadiya zone Trade and Industry office (2010 E.C)

Method of Data analysis

The descriptive and inferential (statistical) analysis was employed with statistical package for social science (SPSS) version 20. Study was utilized multiple linear regression used to examine magnitude of explanatory variable on performance of MSEs (Gujarati, 2004). Regression functions as follows: 
$Y=\beta_{0}+\beta_{1} X_{1}+\beta_{2} X_{2}+\beta_{3} X_{3} \ldots \ldots .+\beta_{n} X_{n}+\varepsilon_{i}$, Where; $Y$ is dependent variable (performance of micro and small enterprises), $\beta_{n}$ is the coefficient of independent variables,

$X_{n}$ is independent variables (Political-legal, Financial, Marketing, managerial experience, Planning and Technological factors) $\varepsilon_{i}$ is error term. Necessary classical multiple linear regression model assumptions were conducted namely, Multicollinearity Normality, Homoscedasticity and Sample size test (Gujarati, 2004). Thus there is no series problem.

\section{Results and discussions}

\section{Regressions Analysis}

For the purposes of analyzing the extent to which the explanatory variables explain the variance in the explained variable, regression analysis was employed. Regression analysis allows the prediction or estimation of the value of one variable (the criterion, dependent, or predicted variable; called as $\mathrm{Y}$ ) from one or more predictor variables (called X)(Keith, 2006).

Researcher Hailmichael (2014) employed multiple linear regression models to assess the factors affecting the performance of MSEs. Also, the researcher adopted multiple linear regression models to identify effects of factor on performance of MSEs. The results of such analysis are narrated as follows.

\section{Correlations}

According to Wajahat et al.,(2010), before the start of regression analysis it is important to check the correlation test between dependent variable and independent variables. The Pearson correlation scale ranges from -1 to +1 , any value greater than zero indicates a positive direct relationship between the two variables, which implies that every increase in the independent variable was lead to the increase independent variable, while any value less than zero indicates a negative indirect relationship between two variables, that means that every increase in the independent variable was lead to the decrease on the dependent variable (Hafiz \& Mohamed 2007).

Table 2 Pearson's correlation coefficient matrix

\begin{tabular}{|c|c|c|}
\hline independent variables & Statistics & Dependent variables(performance) \\
\hline \multirow{2}{*}{ Managerial factor } & Pearson correlation & 0.728 \\
\hline & $\operatorname{Sig}(2$-tailed $)$ & 0.000 \\
\hline \multirow{2}{*}{ Planning factor } & Pearson correlation & .800 \\
\hline & $\operatorname{Sig}(2$-tailed) & .000 \\
\hline \multirow[t]{2}{*}{ Financial factor } & Pearson correlation & .616 \\
\hline & $\operatorname{Sig}(2$-tailed $)$ & .000 \\
\hline \multirow[t]{2}{*}{ Technological factor } & Pearson correlation & .150 \\
\hline & $\operatorname{Sig}(2$-tailed $)$ & .000 \\
\hline \multirow{2}{*}{ Marketing factor } & Pearson correlation & .895 \\
\hline & $\operatorname{Sig}(2$-tailed $)$ & .000 \\
\hline \multirow[t]{2}{*}{ Political factor } & Pearson correlation & .503 \\
\hline & Sig(2-tailed) & .000 \\
\hline
\end{tabular}

**. Correlation is significant at the 0.01 level (2-tailed).

Source: Own survey, 2018

From the above table 4.11 result, it can observed that, marketing is the most correlated variable with performance of MSEs (with the $r$ value of 0.895 ) and it was followed by planning factor (with the $r$ value of 0.800 ), managerial (with the $r$ value of 0.728 ), technological (with the $r$ value of 0.646 ), financial $(0.616)$ and political (with the $r$ value of 0.503 ) respectively.

Furthermore, according to Evans(1987), correlation is an effect size and can be described with absolute value of $\mathrm{r}$ as 00 up to. 19 is "very weak", .20 up to. 39 is "weak", .40 up to. 59 is "moderate", .60 up to. 79 is "strong", and. 80 up to 1.0 is "very strong."

Based on this in Hadiya zone selected MSEs; performance of MSEs is very strongly correlated with the marketing, and planning; strongly correlated with the managerial, technological and financial; and moderately correlated with the political factor.

Table 3: Model summary

\begin{tabular}{cccccc}
\hline Model & R & R Square & $\begin{array}{c}\text { Adjusted R } \\
\text { Square }\end{array}$ & $\begin{array}{c}\text { Std. Error of the } \\
\text { Estimate }\end{array}$ & $\begin{array}{c}\text { Durbin- } \\
\text { Watson }\end{array}$ \\
\hline 1 & $.950^{\mathrm{a}}$ & .902 & .898 & .15498 & 1.785 \\
\hline
\end{tabular}

Source: Own survey, 2018

From table 4.12, it can be seen that $\mathrm{R}$ value is 0.950 . Therefore, $\mathrm{R}$ value indicates that there is a strong positive relationship between performance of MSEs and success factors of MSEs namely; managerial, planning, financial, technological, marketing and political. The adjusted R-square value in the model summary tells the goodness of fit of the model. Adjusted R-square value for this model is 0.898 , which means the six success factors are able to 
measure performance of MSEs at 89.8 percent. However; the remaining 10.2 percent could be some other variables which had not been considered in this study.

The Durbin-Watson statistics shows that the serial correlation of residuals is 1.785 , the value falls within the acceptance range (1.5 and 2.5). This means that there is no auto correlation problem in the data. This concludes that the regression model used in this study was adequate or in other word, the model was fit

Table 4:ANOVA

\begin{tabular}{lccccc}
\hline Model & Sum of Squares & Df & Mean Square & F & Sig. \\
\hline Regression & 31.633 & 6 & 5.272 & 219.492 & $.000^{\mathrm{b}}$ \\
Residual & 3.435 & 143 & .024 & & \\
Total & 35.068 & 149 & & & \\
\hline
\end{tabular}

Source: Own survey, 2018

As seen in above table 4.13, total sum of squares (35.068) is equal to the sum of explained sum of squares (31.633) and residual sum of squares (3.435). A study of these components total sum of squares of is known as the analysis of variance (ANOVA) from the regression viewpoint.

From the above table 4.13, it is identified that the value of F-stat is 219.492 (mean square of regression divided by mean square of residual) and it is significant at $p$ value of $0.00(p<0.05)$. This indicates that the overall model was reasonably fit and there was a statistically significant association between success factors and performance of MSEs. Hence, it can be concluded that success factors have significant impact on performance of MSEs of Hadiya zone in selected sectors of MSEs.

Table 5: Coefficient

\begin{tabular}{|c|c|c|c|c|c|c|c|}
\hline \multicolumn{2}{|c|}{ Model } & \multicolumn{2}{|c|}{$\begin{array}{c}\text { Unstandardized } \\
\text { Coefficients }\end{array}$} & \multirow{2}{*}{$\begin{array}{c}\begin{array}{c}\text { Standardized } \\
\text { Coefficients }\end{array} \\
\text { Beta }\end{array}$} & \multirow[t]{2}{*}{ Sig. } & \multicolumn{2}{|c|}{$\begin{array}{c}55.0 \% \text { Confidence } \\
\text { Interval for B } \\
\end{array}$} \\
\hline & & $\mathrm{B}$ & Std. Error & & & Bound & Bound \\
\hline 1 & (Constant) & .078 & .104 & & .456 & -.128 & .285 \\
\hline & MANAGERIAL & .097 & .035 & .106 & .006 & .028 & .165 \\
\hline & PLANNING & .292 & .038 & .314 & .000 & .216 & .368 \\
\hline & FANANCIAL & .075 & .025 & .098 & .004 & .025 & .125 \\
\hline & TECHNOLOGICAL & .197 & .031 & .219 & .000 & .137 & .258 \\
\hline & MARKETING & .327 & .045 & .373 & .000 & .238 & .417 \\
\hline & POLITICO-LEGAL & .053 & .021 & .077 & .013 & .011 & .094 \\
\hline
\end{tabular}

Source: Own survey, 2018

The relationship of dependent variable $\mathrm{Y}$ to the independent variables $\mathrm{X} 1, \mathrm{X} 2, \mathrm{X} 3 \ldots \mathrm{Xn}$ can be expressed as: $\mathrm{y}=\beta 0+\beta 1 \mathrm{X} 1+\beta 2 \mathrm{X} 2+\beta 3 \mathrm{X} 3+\beta 4 \mathrm{X} 4+\beta 5 \mathrm{X} 5+\beta 6 \mathrm{X} 6+e$. Here, $\beta 0$ is constant and $\beta \mathrm{n}$ is the coefficient of independent variables (Satendra et al., 2011). The researcher was used standardized coefficients to constructing a regression equation Pallant and Julie F, 2005).From the coefficient table 4.14, the substitution of the equation becomes:

Performance of MSEs $=.078+0.106$ managerial +0.314 planning +0.098 financial +0.219 technological + 0.373 marketing +0.077 political.

\section{Hypothesis test result}

Six hypotheses have been tested to answer the research questions based on the research problem and objectives. The hypotheses address each success factors such as; managerial, planning, financial, technological, marketing and political impacts on performance of MSEs. The hypothesis test results were presented as follows.

Hypothesis 1

H1: Management factor has a positive and significant effect on performance of MSEs in selected sub-sectors of Hadiya zone; at $\mathrm{p}$ value of $\leq 0.05$ and $\beta$ value 0.106 .

The value of $p \leq 0.05$ with contribution of $\beta=0.106$ revealed that, management has a significant effect on performance of MSEs. So that, null hypothesis was rejected. Although, beta value of 0.106 indicates that management has positive effect on performance of MSEs. Moreover, the beta value of 0.106 implies that an increase in the effectiveness of management by one unit leads to an increase in performance of MSEs by 0.106 units.

This finding is consistent with the previous study by Hailmichael (2014); Gemach u\&Teklemariam (2016); who reported management is positively and significantly influenced the performance of MSEs.

\section{Hypothesis 2}

$\mathrm{H} 2$ : Planning has a positive and significant effect on performance of MSEs in selected sub-sectors of Hadiya zone ; at $p$ value of $\leq 0.05$ and $\beta$ value 0.314 In the above coefficient table 5 , the $p \leq 0.05$ with contribution of $\beta=0.314$ showed that planning has a significant effect on performance of MSEs. So, the null hypothesis was rejected. Although, beta value of 0.314 indicates that planning has positive effect on performance of MSEs in 
selected sub-sectors of Hadiya zone. Moreover, the beta value implies that an increase in the effectiveness of planning by one unit leads to an increase in performance of MSEs level by 0.314 units.

This finding is consistent with the previous study by Tiruneh (2006); who reported that planning has positive and significant effect on the performance of MSEs.

Hypothesis 3

H3: Finance has a positive and significant effect on performance of MSEs in selected sub-sectors of Hadiya zone; at $p$ value of 0.05 and $\beta$ value 0.098 .

Based on above coefficient Table $5 ; p \leq 0.05$ with contribution of $\beta=0.098$ revealed that finance has significant effect on performance of MSEs. Therefore, the null hypothesis was rejected. Also, beta value of 0.098 indicates that finance has positive effect on performance of MSEs in study area. Moreover, the beta value of 0.098 implies that an increase in the effectiveness of finance by one unit leads to an increase in performance of MSEs by 0.098 units. Hence, in order to increase the performance of MSEs, the study area MSEs operators should improve attributes of finance such as the company's credit institutions, adequate working capital, collateral requirement from lending institutions and Loan application procedures of MSEs.

This finding is similar to the previous research work conducted by Mbugua et al.(2014), Hailmichael (2014); Gemachu \&Teklemariam (2016), Endrias \&Zemach (2015), who reported that finance has positively and significantly influence the performance of MSEs.

\section{Hypothesis 4}

H4: Technology has a positive and significant effect on performance of MSEs in selected sub-sectors of Hadiya zone; at $p$ value of $\leq 0.05$ and $\beta$ value 0.219 .

Based on above coefficient table 5; $p$ value of $\leq 0.05$ with contribution of $\beta=0.219$ revealed that Technology has a significant effect on performance of MSEs. So that, null hypothesis was rejected. Also, beta value of 0.219 indicates Technology has a direct effect on performance of MSEs in study area. Moreover, the beta value of 0.219 implies that an increase in the effectiveness of Technology by one unit leads to an increase in performance of MSEs by 0.219 units. Therefore, the more the study area MSEs invests in the attributes of technology such as licensing bureaucracy, Political influence in team formation, enterprises selection and Tax levied on business.

This finding is consistent with the previous study by Hailmichael (2014), and Gemachu \&Teklemariam (2016); who reported that technology has positive and significant effect on performance of MSEs.

\section{Hypothesis 5}

H5: Marketing has a positive and significant effect performance of MSEs in selected sub-sectors of Hadiya zone; at $p$ value of $\leq 0.05$ and $\beta$ value 0.373 .

Based on coefficient table $5, \mathrm{p} \leq 0.05$ with contribution of $\beta=0.373$ revealed that marketing has a significant effect on performance of MSEs. Therefore, the null hypothesis was rejected. Also, beta value of0.373 indicates that marketing has a positive effect on performance of MSEs of study area. Moreover, the beta value of 0.373 implies that an increase in the effectiveness of marketing by one unit leads to an increase in performance of MSEs by 0.373 units. This indicates that enterprises which have larger market access for their products and services have higher probability of having good performance in the business.

This finding is consistent with the previous study by Hailmichael (2014); who reported marketing is positively and significantly influenced the performance of MSEs .But, it is contrary to the study Gemechu\&Teklemariam (2016); who found in significant influence of marketing on performance of MSEs.

\section{Hypothesis 6}

H5: political-legal has a positive and significant effect performance of MSEs in selected sub-sectors of Hadiya zone; at $p$ value of $\leq 0.05$ and $\beta$ value 0.077 .

Based on coefficient table $5, \mathrm{p} \leq 0.05$ with contribution of $\beta=0.077$ revealed that political-legal has a significant effect on performance of MSEs. Therefore, the null hypothesis was rejected. Also, beta value of 0.077 indicates that political-legal has a positive effect on performance of MSEs of study area. Moreover, the beta value of $0.077 \mathrm{implies}$ that an increase in the effectiveness of political-legal by one unit leads to an increase in performance of MSEs by 0.077 units. This finding is consistent with the previous study by Hailmichael (2014); who reported political-legal is positively and significantly influenced the performance of MSEs.

Moreover, based on the findings of regression analysis, the researcher found that all of the success factors (managerial, planning, financial, technological, marketing and political) had positive and significant effects on performance of MSEs in selected sub-sectors of Hadiya zone.

The Standardized Beta values for each of the different variables have been converted to the same scale; so that, it is better compete them (Pallant and Julie F, 2005). Therefore, researcher was used the standardized Beta coefficients, to compare or prioritize the effects of independent variables(managerial, planning, financial, technological, marketing and political) on dependent variable(performance of MSEs) in selected sub-sectors of Hadiya zone. So that, based on table 4.14 above, marketing factor had a relatively strong and direct effect on performance of MSEs at $\beta$ value of 0.373 and followed by planning factor at $\beta$ value of 0.314 . On the other hand financial factor with the beta value of 0.098 and political-legal factor with the beta value of 0.077 is the poorest 
predictor of performance when it is compared with the other explanatory variables under study.

\section{Conclusion}

This research was conducted in Hadiya Zone (Soro Woreda, Shone town, Shashogo woreda, Misha woreda and hosanna town administration of Hadiya zone) with the prime intent of critically assessing the success factors affecting the performance of MSE operators engaged in food and beverage, wood and metal, merchandise and retail shop, textile and garment activities. Specifically, the study attempted to measure the effects of success factors on the performance of MSEs, to analyze the relationship between success factors and the performance of Micro and small business enterprise operating in the study area and to recommend possible solution to alleviate the problem of MSEs. Based on the objectives and findings of the study, the following conclusions are worth drawn.

From the finding it can be contingent that MSEs with the female and male operators in the overall sample respondents were $55(36.7 \%)$ and $95(63.3 \%$, respectively. This shows that there is a great disparity between male and female operators of MSEs in Hadiya Zone.

Moreover, based on the findings of descriptive analysis, it can be understood that the entire sub sectors agreed on the profitability of the business they are engaged in this was demonstrated by the mean score observed of 3.89 and the standard deviations showed that there is variation in among the response. Whereas the respondents showed their agreement on good sales turnover, on good market share and good customer loyalty showed with score of above 3 point. From this it can be concluded that regardless of other factors the business engaged by operators are profitable.

It can now be seen that planning, marketing and financial factors have the biggest potential to determine the performance of MSEs, followed by technological, management and politico-legal factors. In another word, the result shows that planning, marketing and financial factors are the three top most factors that determine the performance of MSE in the selected area.

Moreover, based on the findings of regression analysis, the researcher found that all of the success factors (managerial, planning, financial, technological, marketing and political) had positive and significant effects on performance of MSEs in selected sub-sectors of Hadiya zone.

Taking the findings, the study concludes that performance of MSEs was very strongly correlated with the marketing, and planning; strongly correlated with the managerial, technological and financial; and moderately correlated with the political factor.

From the finding it can be inferred that, MSEs that have clear information in the availability of appropriate tools and material that make them efficient and competent in their business. Similar to this finding Noghor (2015) claimed that large businesses have the advantage of being technologically advanced, end up poaching the MSE market niche and resulting in MSEs being kicked out of the game. Failure not to employ the latest technology means producing at higher cost than do competitors in the market thus, eventually exiting the market due to tough competition.

The marketing factor showed a positive correlation with performance of MSEs in Hadiya zone. marketing factors are the main success factors affecting the performance of business in Hadiya zone, it has shown a substantial positive correlation with performance $(\mathrm{r}=0.895, \mathrm{p}<0.01)$. Among the marketing factors Searching new market, high quality product for the market, establishing a market network, promotion to attract potential customers and searching adequate market for products were the most important success factors identified in affecting the performance of MSEs in the study area.

It was identified from interviewee that the terms of credit of SNNPR credit and saving share company is not suitable to the operators as the its fixes short repayment period with higher interest rate and service charge of total up to $20 \%$ which is very difficult for MSEs to afford. Obviously, such high loan cost further damages the already low market share and revenue of the enterprises. On the other hand, the interviewees" ${ }^{\text {ec }}$ pointed that the short repayment period scheduled by the MFI put them in worrisome state as they face shortage of market resulting in their inability to repay the loan with in the period stipulated by the MFI. Given the market problem of the MSEs, it is fair to suggest the MFI to effectuate a "grace period policy". Majority of interviewees stated that they frequently use informal sources as main sources of fund suggesting the requirements of collateral and loan application procedures are relatively low or none in case of informal sources. Intimacy and trust of each other used as security in the form of collateral guarantee. In conformity with the finding, according to the Tarfasa et al. , (2016) problem of access to finance is more severe for MSEs as the loan requirement of microfinance institutions (MFIs) is complicated. A large proportion of both micro and small enterprises do not apply for a loan or credit due to cumbersome bureaucracy, limited working premises, and high collateral requirement. Similar to this finding supported by other study, most SMEs prefer to use personal savings and contributions from relatives because they find it very difficult to access financing from micro financial institution and commercial banks due to strict requirements such as collateral security and high repayment costs (Mbugua et al., 2014). 


\section{IX.Recommendation}

The role of MSEs is consistently recognized in employment and income generating and has become a major playing field for policy makers and donors with dual objective of enhancing growth and alleviating poverty. However, MSE growth is multidimensional phenomenon and there is substantial heterogeneity in a number of factors. Policies and support program need to consider the heterogeneous nature of the MSEs. On the basis of the finding and conclusion reached in this study, the following recommendations were forwarded.

$>$ The MSEs operators are better to enhance their marketing skills through proper training and experience sharing with other successful TVET centers, MSEs, and successful private organizations because the educational status of operators in the study area $84 \%$ were below degree level. In addition to this marketing skills, such as setting competitive price of their products, creating good interpersonal relationship with customers in effective manner. Moreover, the government bodies such as Hadiya Zone MSEs office and other stakeholders are better to assist them by searching market for their products which is produced by the MSEs operators, by doing this, they are trying to save them from losses.

$>$ MSEs should be supported able to adopt better technology that will enable them increase efficiency, improve quality and diversity of products. The government should also encourage and support MSEs on how to identify and adopt appropriate technology based on the need of specific types of products, service or consumer needs. The government also needs to reduce importation of technologies and increase the usage of local technologies from the existing MSEs.

\section{Reference}

Adil's. (2007). Challenges and Constraints of Micro and Small Scale Enterprises in Addis Ababa: The case of 2

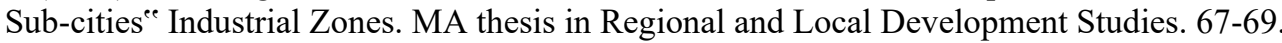

Admasu. ( 2012). Factors Affecting the Performance of Micro and Small Enterprises in Arada and Lideta SubCities, Addis Ababa.A Master's thesis. Addis Ababa University, Ethiopia. 78.

Assegedech, W. (2010). Marketing Strategies for Micro and Small Enterprises in Ethiopia. Ethiopian Business Development Services Network (EBDSN),Addis Ababa., 67-73.

Creswell. (2009). Research Design: Qualitative,Quantitative, and Mixed Methods Approaches. 3rd edition. Landon, Sega publications., 203-216.

CSA, C. S. (2003). Report on small scale manufacturing industries survey. Addis Ababa, Ethiopia.

Endalkachew, M. (2008). Underlying Causes of micro and small business failures in Addis Ketema Sub City Addis Ababa. 22-34.

Ermias, W. (2011). Study on financial sources of micro and small enterprises. Addis Ababa, Ethiopia. 44-56.

Eshetu Bekele and Zeleke Worku. (2010). Women Entrepreneurship in Micro, Small and Medium Enterprises: The Case of Ethiopia. Studies University of south Africa (UNISA) in Pretoria,South Africa, Vol.10\#2November2008, 45-50.

Evans. 95(4), 6.-7. (1987, 4 15). Test of alternative theories of firm growth. Retrieved from Journal of Political Economics,: Retrieved from http://www.jstor.org/stable/pdfplus/1833253.pdf

Gemachu andTeklemariam. (2016). Factors Afecting performance of Micro and small enterprises in south west ethiopia:the case of Bench maji,sheka and kefa zon. Global journals inc.(USA).

Gujarati, D. N. (2004). Basic Econometrics. In M.-H. companies, 4th Ed (p. 105). New York.: .

Hafiz \& Mohamed Nasr. (2007). Working Capital Management and Profitability -Case of Pakistani Firms. International Business Research Papers Vol.3 No.1 March Pp, 279-300.

Hailmichael, M. (2014). Assessing the factors affecting the performance ofMicro and Small Enterprise the case of Yeka sub-city,Addis Ababa. unpublished research, 57-60.

Janet M. Ruane. (2006). Essentials of Research Methods. A Guide to Social Science Research. USA Blackwell Publishing, 39-40.

Lussier, R. (1995). "A nonfinancial business success versus failure prediction model for young firms". Journal of Small Business Management, Vol. 33 No. 1., 45-47.

Lussier, R.N. (1995). , “A nonfinancial business success versus failure prediction model for young firms”, . Journal of Small Business Management, Vol. 33 No. 1., 35-40.

Lussier, R.N. and. Halabi,C.E. (2010). "A Three-Country Comparison of the Business Success versus Failure Prediction Model". Journal of Small Business Management, Vol., 43-49.

Mark Saunders, Philip Lewis and Adrian Thornhill. (2011). Research Methods for Business Students. Fifth edition, FT Prentice Hall, 78.

Mbugua S., Agnes N., Ondabu I. (2014). Factors Affecting the Performance of Small and Micro Enterprises in Limuru Town Market of Kiambu County, Kenya. International Journal of Scientific and Research Publications , 4 (12):1-20.

MoTI. (1997). Micro and small enterprises development strategy. Addis Ababa.

Mulu, G. (2009). "Innovation and Micro enterprises Growth in Ethiopia",world institute for economic 
development research. "Innovation and Micro enterprises Growth in Ethiopia", world.

Mulugeta. (2011). The Livelihoods Reality of Micro and Small Enterprise Operators: Evidences from Woreda One of Lideta Sub-City, Addis Ababa. MA Thesis in Regional and Local Development Studies. RLDS, Addis Ababa University, 56-60.

Pallant and Julie F. (2005). A step by step guide to data analysis using. . Alexander Street: Allen., 45-48.

Paul I. and Rahel Wasihun. (2010). Growth Determinants of Women-operated Micro and Small Enterprises in Addis Ababa. Journal of Sustainable Development in Africa, 37-41.

Praag, M. (2003). "Business survival and success of young small business owners". Tinbergen Institute Discussion Paper, 56-60. Retrieved from Available at http.www.tinbergen.in.

Tarfasa, S., Kebede, K. and Ferede, T. . (2016). Economic growth and employment patterns, dominant sector, and firm profiles in Ethiopia: Opportunities, challenges and Prospects. R4D Working Paper 2016/2, , 36.

Tegegne. (2010b). Micro and Small Enterprises as Vehicles for Poverty Reduction, Employment Creation and Business Development:The Ethiopian Experience. Addis Ababa, Ethiopia: Forum for Social Studies, Research ReportNo.6.

Tegegne Gebre-Egziabhe \& Meheret Ayenew. (2010). Micro and Small Enterprises as Vehicles for Poverty Reduction, Employment Creation and Business Developmen the Ethiopian experience. Addis Ababa, Ethiopia: Forum for Social Studies, Research ReportNo.6.

Teklemariam and Gemechu. (2016). Factors Affecting of SME. Internatonal Journal of Managerial Studies and Research (IJMR), 56-59.

Tiruneh. (2006). Analysis of the Success Factors of Micro and Small Business Enterprises in Addis Ababa. unpublished thesis, 34-37.

Walker, E. and Alan Brown, A. (2004). "What Success Factors are Important to Small business owners?". 28-30.

Workneh., F. (2007). The Constraints of Micro and Small Scale Enterprises in Addressing Employment Opportunity: The case of Kolfe Keraneo Sub-city, Addis Ababa. MA Thesis in Regional and Local Development Studies. RLDS, Addis Ababa University, 65-70 .

Yamane. (1967). Statistics, an Introductory Analysis, Harper and Row, New York. 87.

Zeleke, W. (2009). "Efficiency in management as a determinant of long-term survival in micro,small and medium enterprise in Ethiopia,problems and perspectives in management". 50-52. 